\title{
The Teaching Technique of Grammar in Kampung Inggris Pare
}

\author{
Rafiud Ilmudinulloh and Rafi ${ }^{1}$, Sugeng Bayu Wahyono and Bayu ${ }^{2}$ \\ ${ }^{1,2}$ Graduate School of Yogyakarta State University, Study Program of Instructional \\ Technology \\ Jln. Colombo 1 Karangmalang, Depok Sleman Yogyakarta 55281 \\ +62 274 550836/pps@uny.ac.id \\ $\left\{1\right.$ rafiud12_.2017@student.uny.ac.id, ${ }^{2}$ sugeng_bw@uny.ac.id\}
}

\begin{abstract}
This study aimed to describe: 1) concept, 2) characteristic and 3) advantages and weaknesses of the grammar teaching technique in Kampung Inggris Pare. The study held in two courses namely: KRESNA Institute and SMART Collage where this technique used for the first time. This study used a phenomenological research design. Research subjects consisted, courses founders, teachers, and students. Data were collected by participant observation, in depth interview and documentation. Thence, data was analyzed by IPA (Interpretative Phenomenological Analysis). The results of the study expressed that the teaching technique of grammar was a teacher skill in writing and noting grammar materials in whiteboard by colored markers. The technique was supported by the theories of color psychology and behavioristic learning. This technique helped students to remember the important points in the learning and boost teacher's confidence in teaching, but not influencing to color-blind students and consuming much time in the implementation.
\end{abstract}

Keywords: The Teaching Technique, Grammar, Colored Markers, and Kampung Inggris Pare.

\section{INTRODUCTION}

Survey result from EF EPI (English First of English Proficiency Index for Schools) about Indonesian's English proficiency places Indonesia in 51 st position from 88 countries with the low category. Indonesia is far away from Malaysia in 22nd grade and Singapura in 3rd grade. In the middle of the decline of Indonesian people English proficiency's rate, Kampung Inggris Pare bodies to be "new hope", where one be able to feel speaking English's sensation like in the native country. Kampung Inggris is located in Pelem and Tulungrejo Villages, Pare SubDistrict, Kediri Regency, and East Java Province. The term, Kampung Inggris Pare, was first introduced to the public by a local journalist who gave the special privilege to the villages. The naming of Kampung Inggris is used to represent the existence of English Language Training Institutions (LTI), whose numbers reach 160 LTI and also to bring traffic to students from within and outside the country. Kampung Inggris Pare was established in 1977, marked by the 
establishment of the LTI of Basic English Course (BEC) by Mr. Kalend Osen who later became known as the father of Kampung Inggris Pare.

The grammar program is the most popular program in Kampung Inggris Pare. Grammar is a set of rules that make language easier to understand and meaningful [1]. Grammar is a language for learning languages through a set of rules that describe how words, phrases, clauses and sentences produce meaning [2]. According to the researcher survey to the alumni and students of Kampung Inggris Pare, 97 of the 100 students in Kampung Inggris Pare had attended grammar programs. These facts are influenced by several reasons including, grammar is a material that is difficult to learn when sitting in school, grammar is a basic science in communicating both in spoken and written form, grammar material is tested in English language competency, and tutors in Kampung Inggris Pare has a unique and interesting teaching technique of grammar.

Grammar teaching technique in Kampung Inggris Pare is interesting and rarely found in various places. This teaching technique is in the form of writing or drawing technique using colored markers on a white board medium. Teaching technique is identical to the ability of a teacher to streamline the application of the learning method [3]. Color markers are colors that contrast with white boards such as black, blue, red, green, and purple. The color of the marker is intended to create gradations and give meaning to the writing. This technique is able to produce a chart or creative template grammar illustrated clearly legible, neat, urgent and meaningful. The technique is used to complete the methods of lecture, question and answer and discussion. This technique derives from the teacher's reasoning and creativity to facilitate the way of explaining and also understanding the complex and patterned grammar material.

Kumar in their research proves that the use of colored text on the design of learning materials can effect on the emotional state that finally improves student performance [4]. Colors represent symbolic and cognitive strengths that can facilitate the process of remembering and identifying concepts, and color has an influence on the information processing [5]. Smilek, et al. [6] conducted an investigation to see the color effect in memory performance. They use a number of digits in four color conditions, namely black, white, congruent colors (colors that match the condition of the object) and colors incongruent (colors that do not match the condition of the object) which are then tested on a number of students. The results of the study prove that the memory performance of students in remembering a number of digits that are in congruent color conditions is better than other conditions.

Therefore, the researchers reviewed the phenomena that occur in Kampung Inggris Pare related to the concepts, characteristics and advantages and disadvantages of grammar teaching techniques in the hope that this technique can be learned, imitated and modified by teachers who have difficulty in teaching grammar to students in class.

\section{METHODOLOGY}

This study uses a phenomenological research design to interpret descriptions of concepts, characteristics, and advantages and disadvantages of the technique. The study was conducted in two courses namely KRESNA Institute and SMART ILC, where the grammar teaching technique was first used and preserved as the teaching standard in both places. The research subjects consisted, courses founders, grammar teachers, and students. Data is collected by conducting participatory observation, in-depth interviews, and documentation. And the data is then analyzed using IPA (Interpretative Phenomenological Analysis) which consists of stages: 1) Reading and re-reading; 2) Initial noting; 3) Developing Emergent themes; 4) Searching for connections across emergent themes; 5) Moving the next cases; and 6) Looking for patterns across cases [7]. 


\section{FINDINGS AND DISCUSSION}

\subsection{The Concept of Grammar Teaching Technique in Kampung Inggris Pare}

This teaching technique developed in the early 2000s with being marked the establishment of three courses which were serious about English Grammar, namely ELFAST, SMART ILC, and KRESNA Institute. That is where grammar teaching techniques using colored markers begin to develop and serve as the standard for grammar teaching. Before it finally spread to several courses in Kampung Inggris Pare and is now considered a teaching technique that is commonly used. This technique stems from the habit of a teacher who writes grammar material on colored paper sheets to distinguish the subject matter of the material discussion. After used whiteboards and markers in class, it appears an initiative to change the colors of the paper with the colors of the markers for writing on the board.

This teaching technique is related to the teacher's skills in using colored markers to explain grammar materials in the form of concept maps, charts, patterns, tables, drawings, and examples. The results of using this technique are a learning record that is systematic, directed, concise, clear, legible and meaningful. With the use of this technique in the learning process, students indirectly learn and follow it, so their notes are written using the same color ink as the one used by the teacher on the board. This means that this technique is not only able to shape the cognitive aspects of students but also the psychomotor aspects. The technique is supported by the theory of color psychology which states that color has a psychological impact on perceptions, emotions, memory, and behavior so that the use of color in a situation will be able to stimulate changes in a person's psychological state both positive and negative. Another support comes from behavioristic learning theory, behavioral behavior learning theory states that learning is a change in behavior caused by interactions between stimulus and response. In other word, someone is said to learn when there is a change in behavior shown. This theory relies on input (stimulus) to be able to change a person's behavior while still considering reinforcement factors (reinforcement).

Conceptually, the grammar teaching technique using colored markers is the teacher's skill in writing and recording grammar materials on the board obtained through the process of training and self-habituation. The use of these techniques is intended to create gradations and give meaning or symbols to the writing so that it makes it easier for students to remember and learn the material. The raised colors are used as a stimulus to arouse students' emotions and memory so that learning performance is expected to increase. Based on the development, there are two types of grammar teaching techniques in the Kampung Inggris Pare, when viewed from the consistency of used colors namely:

\subsubsection{The Teaching Technique Using Color Consistently}

The consistency referred to functions that are attached to the color so that used colors can be sure or guessed. Based on its use, this type is divided into two types. Type $A$ uses colors to distinguish between discussion items, and type $B$ uses colors to distinguish items from discussion with sub-items of discussion. In type $A$, the used colors consist of two colors besides black, blue and red. Black is the basic color used to make the framework, charts, and definitions. Blue is used to write grammar patterns or formulas and examples of translations from Indonesian to English, while red is used to write the results of analysis based on patterns or formulas. In type $B$, the colors used consist of four colors other than black, namely blue, red, green and purple. The colors in type $B$ are used sequentially based on the arrangement of the 
discussion (subject matter, sub subject matter, sub subject matter 1 etc.). The black function is almost the same as type $A$, used to create, framework, chart, and definition.

\subsubsection{The Teaching Technique using Colors Inconsistently}

This type of grammar teaching technique can be found in the book Top Grammar: A Guide to Write English written by Mr. Suherman, education practitioner in the English village of Pare. In his book, the use of color is used inconsistently, which means that the colors used in writing have no function of meaning. Color is only used to create gradations or differences between discussion and one another. So that there is no certainty of color used example: in chapter I the red color is used to write the results of the analysis of the discussion, while in chapter II the red color is used to write important notes and example sentences. According to the initiator, inconsistent-used color is intended to create a balance between the right brain and the left brain. Grammar materials that are static or semi-dynamic, patterned and structurally are more processed by the left brain, by which he adds elements of color and images in his book to turn on the activity of the right brain which tends to be more creative, imaginative and artistic.

\section{a. The Characteristics of Grammar Teaching Technique in Kampung Inggris Pare}

The technique of teaching grammar using colored markers has become a characteristic of grammar teaching in English Village Pare. This technique is considered effectively to help beginner students in understanding grammar material fundamentally. Based on the conceptual description of the grammar teaching technique, some characteristics of the technique were obtained those are 1) The teaching technique tends to be teacher centered, 2) It was supported by behavioristic learning theory, 3) A teacher's skills are obtained through a process of training and habituation, 4) The colors of markers are used to stimulate emotions and memory retention in order to increase learning performance, 5) Psychomotor aspect is also considered, 6) It completes methods of lecture, question and answer, and discussion, 7) Mastery of material by a teacher is greatly emphasized. Teachers who do not master the material well will find it difficult to use this technique, 8) The writing produced from this technique requires the criteria for readability, neatness and material integrity, 9) It is supported by the theory of color psychology which states that color has an influence on emotions, memory, and behavior of a person, and 10) It comes from the problems faced by students in learning grammar, such as the difficulty of remembering formulas or patterns and example problems on.

Those are some characteristics that can be revealed, based on the concept building of grammar teaching techniques in Kampung Inggris Pare. It is possible that there are some more characteristics that can be raised from the elaboration and deepening of other types or versions of this teaching technique.

\subsection{The Advantages and Weaknesses of Grammar Teaching Techniques in Kampung Inggris Pare}

Although it has become a very popular and commonly used technique in Kampung Inggris Pare, it does not mean that this technique is perfectly used to teach grammar materials. There are some notes that can be considered by a teacher before applying this technique in the learning process, by which the author invites to see its advantages namely: 1) Facilitating students in understanding the material explained by the teacher, 2) Helping students remember important points of discussion, 3) Increasing the confidence of a teacher in teaching, 4) Encouraging students to be skilled in making notes about grammar material, 5) Being easy to adapt and learn by anyone, whether it's a teacher or student, and 6) Probably boosting the attractiveness of the reader because it has a variety of color variants. And its weaknesses are namely: 1) Greatly 
relying on what the teacher understands and teaches, 2) Not affecting students who experience color blindness, 3) Consuming a lot of time in writing so that the time for discussion is minimal, 4) If not usual, the teacher's hand and clothing will get dirty quickly with ink markers, 5) If it is not handled properly, the whiteboard will look dirty because it has ink from various types of colors. By that, before the board is used, it is ensured that it is clean of scribbled posts, and 6) Learning becomes less challenging for students who already understand the material.

\subsection{Discussion}

There are three main problems making Indonesian students experience difficulties in learning English [8]. Firstly, the formation of words, phrases and sentences in Indonesian is different from English. Secondly, words in English are spoken differently. Thirdly, the meaning in English words is determined by context. To make it easier for Indonesian students to learn English grammar, tutors at English Village Pare initiated a grammar teaching technique that utilizes colored markers. In the world of EFL teaching, this technique is known as "boardwork". Boardwork techniques refer to the learning process that maximizes the function of the whiteboard to present and explain the material [9]. The board is an integral part of English as a Foreign Language classroom, because your board is a record of the lesson and your students are likely to write down whatever is on the board [10]. Boardwork is the skill of a teacher to explain EFL material through the board clearly and effectively. Using colors, circles and lines makes it easier for students to understand material [11]. The basic colors used are contrasting colors with blackboards such as black and blue, while complementary colors can use red and green for highlighting, underline, circling, identifying specific features, stress patterns, phonetic symbols, interaction patterns, and syllable boundaries [12].

Grammar teaching techniques in Kampung Inggris Pare also have similarities with the model of grammar teaching known as PPP (Presentation, Practice and Production). The model consists of three stages. In the first stage, presentation, teacher teaches structure or rules in grammar. In the second stage, practice, students practice these rules in making examples and completing assignments and exercises. And the third stage, production, students develop their grammar understanding in productive skills (spoken and written form) [13]. The PPP model has drawn criticism from experts such as Scrivener and Lewis because it is considered not to reflect the nature of language and learning [14].

This criticism arises because the technique tends to be deductive approach in its application, so the learning process seems to be dominated by a teacher. Widodo [15] states that the deductive approach is termed rule-driven learning, where the teacher teaches grammar by presenting grammar rules and giving examples of sentences. This approach has several disadvantages including: 1) the likelihood of students feeling frustrated and confined because they are bound by grammatical rules that have been explained in the beginning, causing excessive caution, 2) grammar explanation of a teacher-fronted, classroom transmission style, 3) an approach to the belief that learning is a case of knowing the rules [5]. Responding to this criticism, Johnson and Bryne in Hamer [14] offer a more flexible alternative strategy, in which a teacher and student can decide to start learning from which stage, practice, production or presentation.

Parenting grammar teaching techniques both on the deductive approach and inductive approach must have advantages and disadvantages [5]. Clandfiled, et al. [11] proposed several considerations from aspects of students, language and context to determine the most appropriate approach to use. From the aspects of students that need to be considered are the level of material understanding, age, learning style and interests, and expectations. From aspects of language that needs to be considered is the level of complexity or difficulty of the material, new material or 
material that has been studied by students, the similarity of concepts or structural student's language. In terms of the context that should be considered is the time and resources available.

The teaching technique of grammar in Kampung Inggris Pare is not appropriate if it is said not to reflect the nature of language and learning because in its development, the technique departs from manifestations of teaching experience that are long enough to form teaching techniques that are unique in English Pare Village using colored markers. This technique will continue to be maintained and developed with reference to the principles of good presentation, namely memorable, clear, effective and appropriate.

\section{CONCLUSION}

Conceptually, the grammar teaching technique using colored markers is the teacher's skill in writing and recording grammar materials on the board obtained through the process of training and self-habituation. The use of these techniques is intended to create gradations and give meaning or symbols to the writing so that it makes it easier for students to remember and learn the material. This grammar teaching technique is characterized by teacher centered approach, behavioristic learning theory, complement for the lecture, answer-question, and discussion methods, the mastery of lesson, colored markers, the criteria of readability, tidiness, and material integrity, and the solution of learning problem. Although it has become a very popular and commonly used technique in Kampung Inggris Pare, it does not mean that this technique is perfectly used to teach grammar materials because it has advantage and disadvantage in use. Though recently learning tends to student-centered learning and integrates instructional technology. Course founders and teachers in Kampung Inggris Pare have greatly believed that the technique stills relevant, affordable, economical, and learnable to teach grammar so that it stills sustainable in Kampung Inggris Pare.

\section{Acknowledgments}

Thanksgiving to God with saying Alhamdullilah. Finally this article can be solved with all the limitations. Not to forget, the author also thanked all those involved in this research. Especially to Mrs. Sri Suharti, founder of KRESNA Institute, who welcomed the presence of researchers and was willing to provide information related to the topic of research. The same feeling also the author addresses to Mrs. Uun Nurcahyanti, founder of SMART ILC, who has been happy to allow conducting research and also provide information related to this research. To Mr. Suherman, Mr. Ferry and Mr. Hari Thanks you for your thoughts, time and discussion during the research. To all my friends, tutors and students who are willing to share their experiences, I thank you. Hopefully there will be more opportunities to learn with all of you.

\section{References}

[1] J. Coghill and S. Magedanz, English grammar. Wiley, 2003.

[2] M. Swan, Practical English usage. Oxford University Press, 2005.

[3] H. Uno, B, Model Pembelajaran: Menciptakan Proses Belajar Mengajar Yang Kreatif dan Efektif. Jakarta: Bumi Aksara, 2009.

[4] S. Kumar, J. Sterkenburg, J. Diekfuss, and M. Jeon, "Color effects on students' emotions and task performance in a web-based learning management system," Proc. Int. Conf. Multimed. Comput. Interact., no. July, pp. 1-4, 2013.

[5] Scott Thornbury, How to Teach grammar. Essex: Pearson Education Limited, 2004. 
[6] P. Smilek, Daniel \& Dixon, Mike \& Cudahy, Cera \& M Merikle, "No Title," Synesthetic Color Exp. Influ. Mem. Psychol. Sci., vol. 13(6), pp. 548-552, 2002.

[7] J. A. Smith, Psikologi kualitatif: Panduan praktis metode riset. Yogyakarta: Pustaka Pelajar, 2009.

[8] Supriusman, "Methods and Techniques of Teaching Grammar in ELT," in SELT Padang, 2014, pp. 3-7.

[9] "Boardwork - Teflpedia." [Online]. Available: https://teflpedia.com/Boardwork. [Accessed: 04-Apr-2019].

[10] T. Academy, "Why Boardwork Is So Important in The Classroom.," 2016. [Online]. Available: https://www.theteflacademy.com/blog/2016/12/why-boardwork-is-soimportant-in-the-efl-classroom/.

[11] et al. Clandfield, Straightfoward: Guide to Presenting Grammar. London: Macmillan Education., 2009.

[12] D. Gates, "How to Use the Board Effectively in ELT," 2017. [Online]. Available: https://www.teachenglishspain.com/use-the-board-elt/. [Accessed: 04-Apr-2019].

[13] J. C. Richards, Communicative Language Teaching Today. 2006.

[14] J. Harmer, How to Teach English. 2007.

[15] H. P. Widodo, “Approaches and procedures for teaching grammar," English Teach. Pract. Crit., vol. 5, no. 1, pp. 122-141, 2006. 